\title{
夏季建設現場における飲水とファン付き作業服による脱水の低減に関する研究
}

建設作業での発汗量、脱水量、飲水量、およびWBGT・活動量の関係

\section{REDUCTION OF DEHYDRATION BY WATER INTAKE AND VENTILATED WORKING WEAR AT A CONSTRUCTION SITE IN SUMMER}

Relation between the sweet rate, body weight loss, water intake, WBGT and activity during construction work

\author{
山崎慶太茥, 葉原浩平*2, 染谷俊介*3, 濱田靖弘*4, 小林宏一郎*5
}

Keita YAMAZAKI, Kohei KUWABARA, Shunsuke SOMEYA, Yasuhiro HAMADA and Koichiro KOBAYASHI

\begin{abstract}
To obtain basic data for prevention of heat stroke during construction work in a hot environment, we analyzed the effects of wearing ventilated work wear (VWW) and the sweat rate (SR), the rate of water intake (RWI), and body weight loss (RBWL) in experiments of an artificial climate chamber and outside construction site in August. We supposed there is a limit to the amount of water that workers in a construction site can drink. Thus, we verified that RBWL increased with increasing WBGT mainly due to insufficient RWI, but could be partly decreased by using VWW, which decreased the SR.
\end{abstract}

Keywords : Heatstroke, ventilated working wear, Sweat rate, Dehydration, Water intake, Activity 熱中症，ファン付き作業服，発汗量，脱水量，飲水量，活動量

\section{1. はじめに}

われわれは、ファン付き作業服(VWW)が夏季暑熱下の建設現場の 作業員の生理・心理反応に及ぼす影響を評価するために、2016 年 7,8月に東京都内の建設現場で実測を行った 1)。この現場では、体 重減少量を測定しておらず、環境条件や作業量も統一できなかった ため、気温 $\left(29,34^{\circ} \mathrm{C}\right) 、$ 職種 $($ 鉄筋工・型枠大工) 毎の模擬作業、VWW 以外の服装をそれぞれ統一した被験者実験を対象に、2017 年 5, 6 月に人工気候室で行った ${ }^{2)}$ 。その結果、 $\left.34^{\circ} \mathrm{C} （ 50 \%\right)$ の環境では、 VWW を着用している被験者の平均皮膚温や胸部・背部皮膚温は、 VWW を着用していない被験者よりも有意に低いことが明らかとな った。また、VWW 着用の有無で汗の蒸発密度 $\left[\mathrm{g} /\left(\mathrm{h} \cdot \mathrm{m}^{2}\right)\right]$ に有意な 差は見られなかったものの、着衣に残った汗の量はVWW を着用し た方が有意に少なかった。このことから発汗密度 $\left[\mathrm{g} /\left(\mathrm{h} \cdot \mathrm{m}^{2}\right)\right]$ は VWW を着用した方が有意に少ないことが示された。この結果を現場で確 かめるべく、2017 年 8 月 3 8 日（6 日は休日）に東京都内の屋外 建設現場において型枠大工や鉄筋工を対象として実測を行った 3 。 気温 $24 \sim 35^{\circ} \mathrm{C}$ の環境において、VWW を着用している被験者の平均
皮膚温や胸部・前腕皮膚温はVWW を着用していない被験者よりも 有意に低かったが、大腿・下腿皮膚温に有意な差は見られなかった。 また、汗の蒸発密度と飲水密度にも有意な差は見られなかった。現 場では裸体状態の体重減少量を測定できないため、人工気候室での 結果をもとに蒸発密度から発汗密度を推定する回帰式を求めた。回 帰式から推定された発汗密度は有意差が見られ、VWWを着用した 方が発汗量は少ないことが示された。発汗量の増大は皮膚温と深部 体温の影響で決まるので ${ }^{4)} 、 \mathrm{VWW}$ の影響で平均皮膚温が下がった 分、発汗量が少なくなったと推定され、VWW が脱水を予防寸る可 能性が示唆された。芳田は、熱中症を予防するためには、脱水と高 体温を抑制することが重要であるので、熱中症の発生状況を調查し、 温熱ストレスを高めて熱中症を多発させる気象状況や、着衣・帽子 などの環境要因を明確に示寸必要があると指摘している5)。しかし ながら、脱水に影響すると想定される建設現場での発汗量、脱水量、 飲水量および環境条件（WBGT など）との関係については、VWW の効果を含めて充分検証されていない。

運動現場での発汗量、脱水量、飲水量に関する既往の研究として、

\footnotetext{
*1 株竹中工務店技術研究所 博士(工学) / 岩手大学理工学部 客員教授

*2 釧路工業高等専門学校 准教授・博士 (工学)

*3 侏竹中工務店技術研究所 研究主任

*4 北海道大学大学院工学研究院 教授 $\cdot$ 博士 (工学

* 5 岩手大学理工学部 教授・博士 (工学)
}

Takenaka Research \& Development Institute, Dr.Eng./

Visiting Prof. of Iwate University

Assoc. Prof., National Institute of Technology, Kushiro College, Dr.Eng.

Assoc. Chief Researcher, Takenaka Research \& Development Institute

Prof., Graduate School of Engineering, Hokkaido Univ., Dr.Eng.

Prof., Dept. of Systems Innovation Engineering, Iwate University, Dr.Eng. 
佐藤らは、気温 $33^{\circ} \mathrm{C}$, 相対湿度 $60 \%$ の工気候室内での男子学生 を対象とした自転車エルゴメーター $(600 \mathrm{kpm} / \mathrm{min}) 60$ 分間の運動を 行った。体重減少量(脱水量)は、水分補給量(飲水量)の減少に伴って 増大し有意な相関関係が認められる一方、発汗量は水分補給量の変 化にもかかわらずほぼ一定 $(12.1 \sim 15.2 \mathrm{~g} /(\mathrm{kg} \cdot \mathrm{h}))$ であるとしている 6)。運動現場での WBGT と発汗量等の関係については、丹羽らが、 男子バレーボール部員 11 名を対象として 4 月から 7 月を除く 9 月 までの 5 か月、一定時刻(16:30〜19:30)練習時を調查した。その結 果、発汗量、水分補給量(飲水量)は WBGT の増大に伴って増大寸る 有意な関係が認められたが、体重減少量(脱水量)はWBGT の変化に 関わらず一定 $(4.8 \sim 5.7 \mathrm{~g} /(\mathrm{kg} \cdot \mathrm{h}))$ であったとしている7)。さらに中井 らは、大学の運動現場で春季・夏季に調査した。その結果、発汗量 と飲水量は、WBGT との間には相関関係が認められ、WBGT が上 昇すると直線的に増すが、自由に水分を摂取できる練習環境では、 体重減少量(脱水量) はWBGT の変化に関わらず一定 $(2.02 \pm 0.43 \mathrm{~g} /(\mathrm{kg} \cdot \mathrm{h})$ : 野球部員、4.11 $\pm 1.04 \mathrm{~g} /(\mathrm{kg} \cdot \mathrm{h})$ : アメリカン フットボール部員)であったとしている 8)。自由飲水の実施により、 体重減少量(脱水量)は、環境温度の変化の影響を受けないことが示 された。

以上のように、運動現場での暑熱環境下の熱中症予防のための水 分補給の効果や発汗量、飲水量および脱水量と環境(WBGT)の関係 については検証されているが、建設現場についての検討例は少ない。 そこで本稿は、人工気候室(Artificial chamber) 実験（以降 $\mathrm{AC}$ 実験 と称す） 9)、暑熱環境下の屋外建設現場(Construction site)実測（以 降 CS 実測と称す) ${ }^{3)}$ 、それぞれの飲水量と発汗量、脱水量の関係お よびそれらの水分量と環境(WBGT)の関係について検討し、両者を 比較する。さらに、活動量と水分量の関係、実際の現場で作業前か ら作業後の脱水量・脱水率を検証する。建設現場での脱水の低減の ための飲水と VWW の効果について、環境(WBGT) ・ 活動量の影響 を考慮しながら、先行研究の運動現場と比較し、今後の建設現場で の熱中症対策の基礎データとすることを目的とする。

\section{2. 実験・実測方法と解析方法}

\section{1 人工気候室実験}

$\mathrm{AC}$ 実験は、2018 年 6 月に北海道大学工学部フロンティア応用科 学研究棟内の人工気候室にて行われた。健康な $20 \sim 60$ 歳の男性型 枠大工 9 名を被験者として、被験者は二人一組とし、1 日は二名と
も VWW 着用、もう 1 日は二名とも VWW 非着用とした。服装は、 長袖 $\mathrm{T}$ シャツ、ズボン、靴下、靴、ヘルメット、腰袋である。VWW 着用条件では, 長袖 T シャツの上に VWW を着用している。室温は $34^{\circ} \mathrm{C}$ 、相対湿度は $50 \%$ とし、型枠大工の模擬作業を行わせた。空 調服以外の服装、それぞれの条件を統制し、VWW、時間帯の効果 を評価できるようにした。作業時間は、午前、午後それぞれ前半 40 分、休息 20 分、後半 40 分の計 100 分である。衣服を着用した状態 での体重（着衣時体重）と飲水量は $0,40,60,100$ 分目に測定し、 裸体時体重は $0,50,100$ 分目に測定した（AM, PM 共に)。実験開 始前に、被験者には $500 \mathrm{~mL}$ のスポーツドリンクを摂取させ、作業 中も自由に飲水できるようスポーツドリンクを用意した。飲料容器 の減少量（飲水量）を記録したが、作業中トイレを使用した被験者 はいなかった。文献 2) と同様に、作業中の各部位皮膚温、心拍、活 動量を測定した。活動量は左手首にライフレコーダ (A\&D Corp.) をとりつけ各作業時間帯の平均を求め、体重・飲水量は、電子天び ん GP-100K (T\&D Corp.)を用いて、それぞれ測定した。Fig. 1 に、 発汗量 $(\mathrm{SR})$, 飲水量 $(\mathrm{RWI})$, 裸体時脱水量 $(\mathrm{RBWL})$, 着衣時脱水量 (RBWLC), 着衣残留汗量(SCC), 蒸発量(ER)の関係を示す。式で表 すと以下のとおりである。

RBWL $=$ 実験前裸体時体重一実験後裸体時体重

RBWLC $=$ 実験前着衣時体重一実験後着衣時体重

$\mathrm{SCC}=\mathrm{RBWL}-\mathrm{RBWLC}$

$\mathrm{ER}=\mathrm{RBWLC}+\mathrm{RWI}$

$\mathrm{SR}=\mathrm{RBWL}+\mathrm{RWI}$

それぞれの量を作業時間 $[\mathrm{h}]$, 体重 $[\mathrm{kg}]$ で除した值を「密度」と称 し、文献 6)、7)、8）と比較する。通常、建築系の研究では、放熱量 を検討するために、それぞれの水分量を作業時間・体表面積で除し た值を用いることが通常であるが、本報では、運動現場での文献 6),7),8) と比較するために、発汗・飲水・脱水の水分量を作業時間 [h]、 体重 $[\mathrm{kg}]$ で除した值を「密度」として用いることとした。また、実 験時期の札幌の日平均気温は $2018 / 6 / 11 \sim 6 / 16$ に $9.4 \sim 14.1^{\circ} \mathrm{C}$ 10), $6 / 26 \sim 6 / 29$ に $\left.15.9 \sim 20.8^{\circ} \mathrm{C} 10\right)$ であり、人工気候室 $\left(34^{\circ} \mathrm{C}\right)$ に比 べて外気温が低い期間に実験を実施したことを考慮し、本報では、 午前、午後の $60 \sim 100$ 分の時間帯で皮膚温などが定常状態に達した と考え、その 40 分間の平均值を解析に用いることとする。本研究 は、北海道大学工学系研究倫理審査委員会の承認 (海大工第 153 号、 平成 30 年 5 月 7 日）を得て実施した。被験者には、実験前に予め

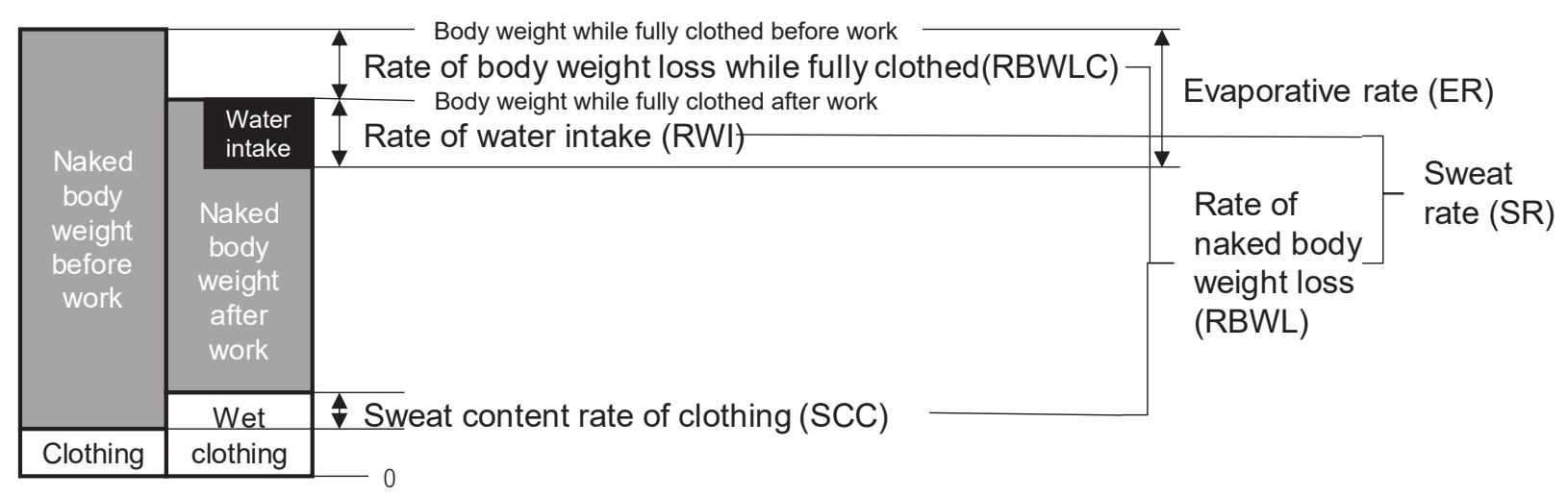

Fig. 1 Sweet rate, water intake, body weight loss, body weight loss while fully clothed, evaporative rate and sweat content of clothing. 


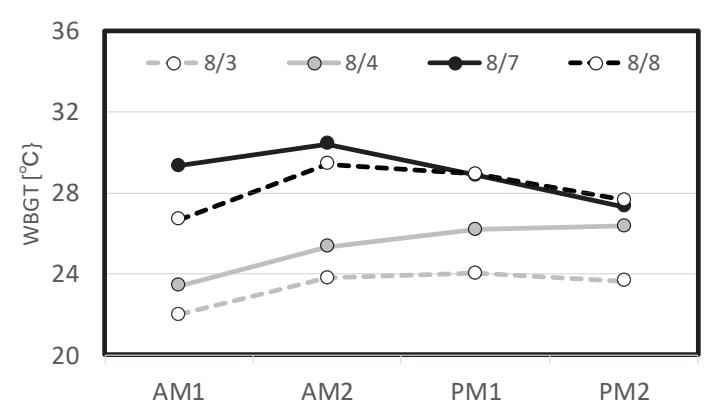

Fig. 2 WBGT at a construction site

実験内容を説明し、承諾を得ている。

\section{2 現場実測}

CS 実測は文献 3)のデータを用いる。建設作業は、基本的に昼休 み(12〜13 時)を挟んだ 8〜17 時に行われ、各 30 分の休憩を挟んで 午前 2 回、午後 2 回の計 4 回の作業時間帯(AM1, AM2, PM1, PM2 と称す)に分けられている。作業中の飲水にはスポーツドリンクを用 意し、着衣時体重、飲料容器の測定を $\mathrm{AM} 1, \mathrm{AM} 2, \mathrm{PM} 1, \mathrm{PM} 2$ の前 後に計 8 回行った。その減少量から着衣時脱水量(RBWLC)、飲水 量(RWI)を求め、AC 実験と同様にそれぞれの量を作業時間[h], 体重 $[\mathrm{kg}]$ で除した值「密度」として比較する。CS 実測では、各作業時間 帯で活動量が一定ではないので、時間帯を通しての平均值で評価す ることにした。ただし、着衣時脱水量 $[\mathrm{g}]$ 、飲水量 $[\mathrm{g}]$ を用いて解析す る際は、それぞれ BWLC、WI とした。また現場の WBGT は、式(6) を用いて求めた。ただし、湿球温度は自然湿球温度ではなく、気温 と相対湿度から計算された通風湿球温度である。

$\mathrm{WBGT}=0.7 \times$ 通風湿球温度 $+0.2 \times$ 黒球温度 $+0.1 \times$ 気温

Fig. 2 に、 $8 / 5$ を除く測定日の各作業時間帯の WBGT の平均値を 示す。本報では、WBGT が警戒〜稂重警戒を示した 8/7, 8 の 2 日間 (WBGT : $26.7 \sim 30.4^{\circ} \mathrm{C}$ 、以降暑い日と称す) と ${ }^{11}$ 、注意〜警戒を示 した 8/3, 4 の 2 日間 (WBGT : 21.0 26. $4^{\circ} \mathrm{C}$ 、以降涼しい日と称す) に分けて分析した。被験者は、型枠大工 4 名 $(20 \sim 68$ 歳) と鉄筋工 1 名(24 歳)の合計 5 名のデータを使用した。被験者の型枠大工は、地 上の休蒩所から RC 構造物の 5〜6 階の作業場まで、階段を使って 徒歩で作業場まで移動し、鉄筋工は休憩所に隣接する地上部で主に 作業した。CS 実測では SR を測定できないため、ERから SR を推 定する式 3)を用いて VWW 着用時、VWW 非着用時の $\mathrm{SR}_{\mathrm{with}} 、 \mathrm{SR}_{\mathrm{without}}$ を求めた。RBWL は、式(5)を用いて算出した注1)。

\section{3 VWW の効果検証}

$\mathrm{AC}$ 実験では、各時間帯で求めた SR, RWI, RBWL, RBWLC, ER, 活動量について、同一被験者の同じ時間帯を比較する対応のある $\mathrm{t}$ 検定により VWW の効果について検証する。その後、RWI と SR, RBWL の関係について検証し、水分補給・VWW の効果を、同様の 環境の運動現場実測 6)-8) と比較して評価する。

CS 実測では、まずRWI, RBWLC, ER, 活動量について、涼しい 日、暑い日で同一被験者の同じ時間帯で比較する対応のある $\mathrm{t}$ 検定 によりVWW の効果について検証し、AC 実験結果と比較する。そ の後、WBGT と、SR, RBWL, RWI それぞれの関係について、VWW の有無で評価する。次に RWI と SR, RBWLのそれぞれの関係での、

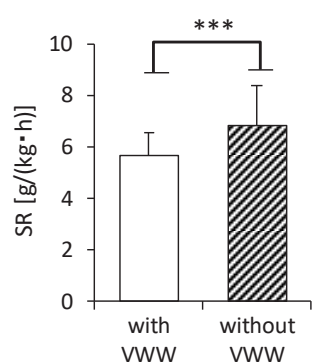

(a) Sweat rate

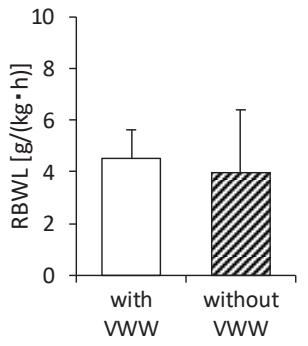

(c) Rate of naked body weight loss

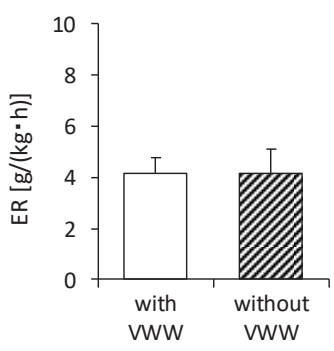

(e) Evaporative rate

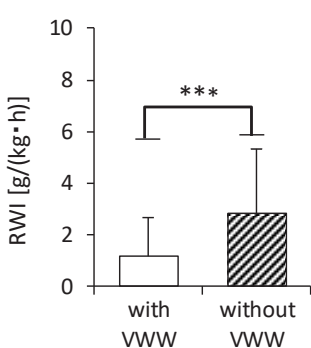

(b) Rate of water intake

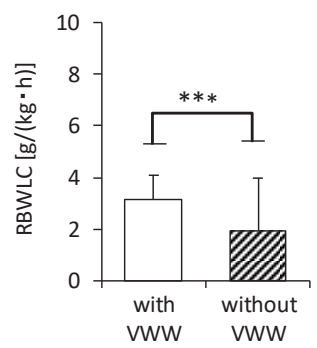

(d) Rate of body weight loss while fully clothed

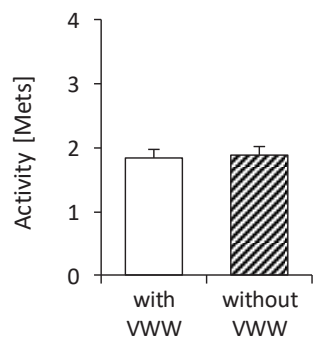

(f) Activity
Fig. 3 Comparisons of sweat rate, rate of water intake, body weight loss and body weight loss with clothing, evaporative rate and activity between with and without VWW measured in artificial climate chamber at $34^{\circ} \mathrm{C}, 50 \%$

水分補給・VWW の効果について AC 実験、運動現場実測 6) と比較 して評価する。さらに、 $\mathrm{AC}$ 実験の活動量と SR, RWI, RBWL の関 係を検証して、水分量における活動量の影響を評価する。最後に、 $\mathrm{AC}$ 実験の結果を参照して、VWW や活動量が、建設現場での BWLC の一日の変動に及ぼす影響を総合的に検証する。

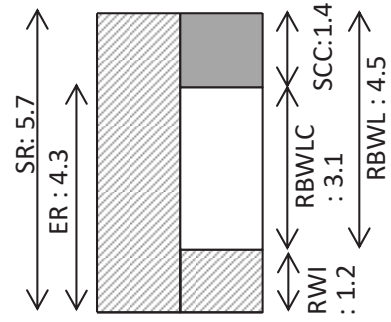

(a) With VWW

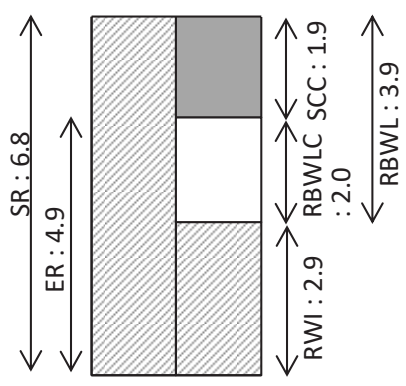

(b) Without VWW
Fig.4 Comparisons of SR, ER, RWI, RBWLC, SCC and RBWL between with and without VWW measured in artificial climate chamber at $34^{\circ} \mathrm{C}, 50 \%$. Unit: $\mathrm{g} /(\mathrm{kg} \cdot \mathrm{h})$ 


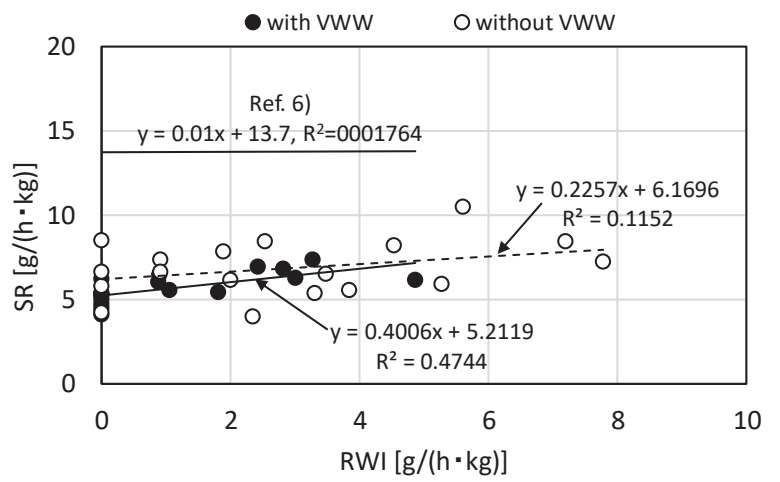

(a) Sweat rate

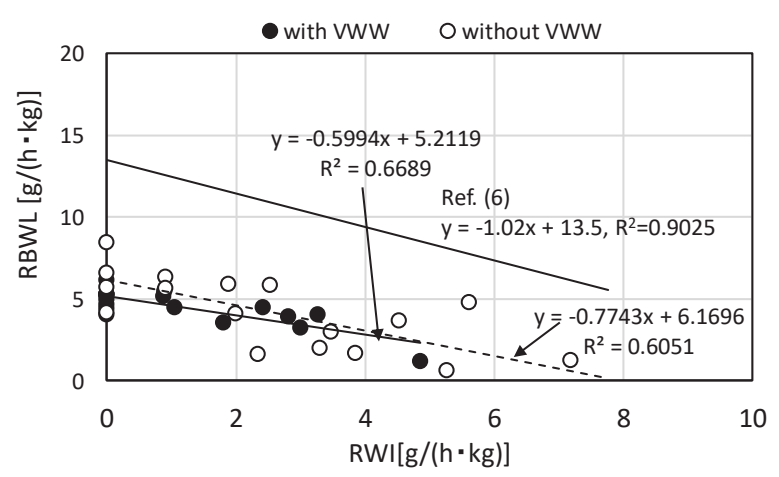

(b) Rate of naked body weight loss

Fig. 5 Relation between rate of water intake, and sweat rate and rate of body weight loss with and without VWW measured in artificial climate chamber at a fixed temperature $\left(34^{\circ} \mathrm{C}, 50 \%\right)$ and in ref. 6).

\section{3. 実験結果}

\section{1 人工気候室実験}

\subsection{1 水分量・活動量における VWW の効果}

Fig. 3 に、SR, RWI, RBWL, RBWLC, ER, 活動量の $\mathrm{t}$ 検定の結果 を示す。(a)VWW を着用していない被験者の $\mathrm{SR}$ (平均值 $6.8 \mathrm{~g} /(\mathrm{kg}$ ・ h))は、 VWW 着用した場合(平均值 $5.7 \mathrm{~g} /(\mathrm{kg} ・ \mathrm{~h})$ ) より有意に高值を 示した $(\mathrm{p}<0.001)$ 。(b)RWI は、VWW を着用しない方(平均值 $2.9 \mathrm{~g} /(\mathrm{kg} \cdot \mathrm{h}))$ が、着用した場合 $($ 平均值 $1.2 \mathrm{~g} /(\mathrm{kg} \cdot \mathrm{h}))$ よりも有意に高 值を示した $(\mathrm{p}<0.001) 。(\mathrm{c}) \mathrm{RBWL}$ では、VWW ありとVWWなしで 有意な差が認められなかった。(d) VWWを着用した被験者の RBWLC(平均值 $3.1 \mathrm{~g} /(\mathrm{kg} \cdot \mathrm{h}$ )) は、VWW を着用しない場合(平均值 $1.9 \mathrm{~g} /(\mathrm{kg} \cdot \mathrm{h}))$ より有意に高值を示した $(\mathrm{p}<0.001)$ 。VWW を着用し ないと、VWWを着用した場合に比べて SR が有意に高くても、RWI が有意に高かったので、RBWLC が有意に低くなったと考えられた。 その一方、(d)ER では、VWW あり (平均值 $4.2 \mathrm{~g} /(\mathrm{kg} \cdot \mathrm{h}))$ と VWW な し(平均值 $4.1 \mathrm{~g} /(\mathrm{kg} \cdot \mathrm{h}))$ はほぼ同等で、有意な差が認められなかっ た。(e)活動量も、VWW あり (平均值 $1.84 \mathrm{Mets}$ ) と VWW なし(平均 值 $1.88 \mathrm{Mets}$ )はほぼ同等で、有意な差が認められなかった。

Fig. 4 に、SR, RWI, RBWL, RBWLC, SCC, ER の関係を、VWW

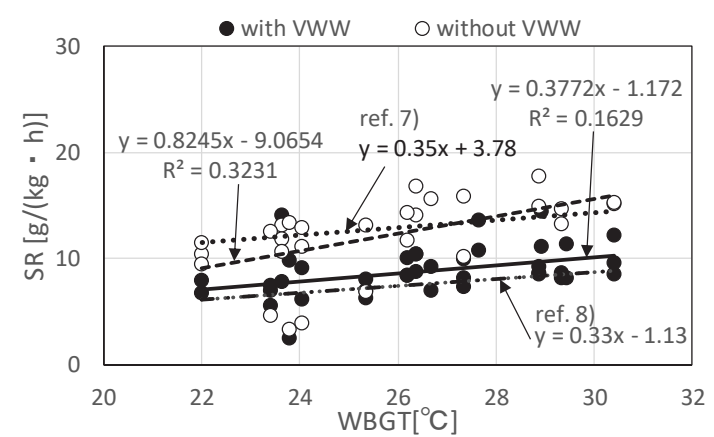

(a) Sweat rate

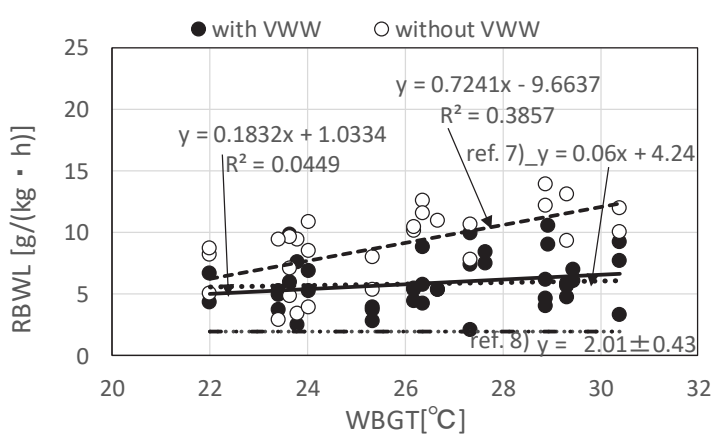

(b) Rate of naked body weight loss

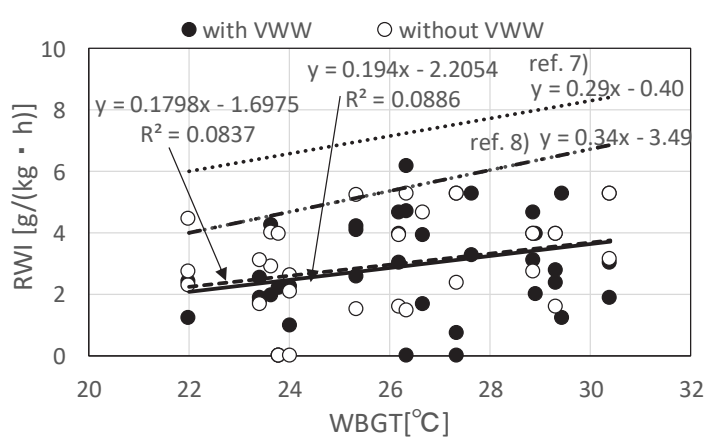

(c) Rate of water intake

Fig. 6 Relations between WBGT and sweat rate, rate of body weight loss and water intake with and without VWW measured in a construction site and in ref. 7 (Valley ball players) \& 8 (Baseball players).

の有無ごとに示す。 VWW を着用すると $\mathrm{SCC}(1.4 \mathrm{~g} /(\mathrm{kg} ・ \mathrm{~h}))$ は $\operatorname{RBWL}(4.5 \mathrm{~g} /(\mathrm{kg} \cdot \mathrm{h}))$ の $31 \%$ 、VWW を着用しないと $\operatorname{SCC}(1.9 \mathrm{~g} /(\mathrm{kg} \cdot \mathrm{h}))$ は RBWL(3.9g/(kg・h ) ) の 49\%となり、SCC が RBWL に大きな割合を占めている。

\section{1 .2 飲水密度と発汗密度、脱水密度の関係}

Fig. 5 に、RWI と SR、RBWL の関係を、それぞれ文献 6) の近 似直線と比較して示寸。文献 6) の測定は、被験者が、上半身裸体、 下半身水泳パンツ着用で実施されたので、本実験の RBWL と比較 した。Fig. 5 は、N=38 のデータであるが、RWIが 0 であった被験 者が 13 名いた。 


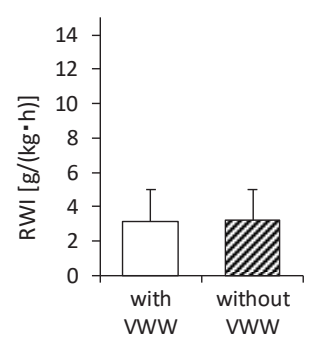

(a) Rate of water intake

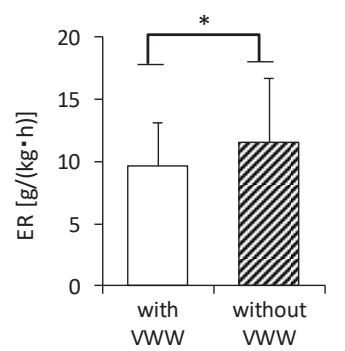

(c) Evaporative rate

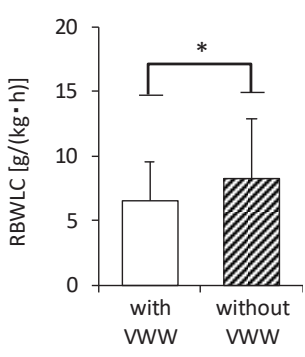

(b) Rate of body weight loss while fully clothed

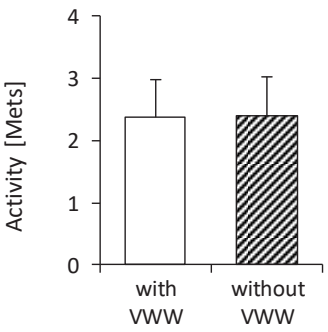

(d) Activity
Fig. 7 Comparisons of rate of water intake, body weight loss with clothing, evaporative rate and activity between with and without VWW measured in a construction site.

(a)VWW 着用時の SR は 5〜 $8 \mathrm{~g} /(\mathrm{kg} ・ \mathrm{~h}$ )で、RWI との間に有意な 相関関係 $(\mathrm{r}=0.689, \mathrm{p}<0.01)$ が認められたが、VWW を着用しないと $4 \sim 10 \mathrm{~g} /(\mathrm{kg} \cdot \mathrm{h})$ で相関がなく、両者とも RWI の変化に関わらずほぼ 一定の範囲にあった。(b)RBWL は、VWW 着用の有・無で、RWI と有意な相関関係 $(\mathrm{r}=-0.863, \mathrm{p}<0.001, \mathrm{r}=-0.887, \mathrm{p}<0.001)$ が見られ た。RWI の増加に伴って RBWL は減少し、近似直線はほとんど差 がなかった。ほぼ同じ環境温度 $\left(33^{\circ} \mathrm{C}\right)$ 下での文献 6) も同様に、SR は RWI の変化に関わらずほぼ一定 $(12.1 \sim 15.2 \mathrm{~g} /(\mathrm{kg} \cdot \mathrm{h}))$ の範囲にあ り、RWI の増加に伴って減少し、本実験とほほ同じ傾向が見られた。 SR, RBWL とも本実験結果の概祙 2 倍の大きさだった。これは、文 献 6)の自転車エルゴメーターによる代謝量が $250 \mathrm{~W} / \mathrm{m}^{2}$ であり、本 実験の模擬作業の平均活動量 $83 \mathrm{~W} / \mathrm{m}^{2}$ より高かったことが要因と して考えられる。暑熱環境が厳しくても一定の環境温度下では、建 設作業においても、文献 6) と同樣に、発汗密度 (SR) は飲水密度 (RWI) に依存せずほぼ一定なので、RBWL は RWI の増加によって減らす ことができ、VWW 着用有無に関係なく水分補給によって脱水密度 を減らせることがわかる。

\section{2 屋外現場実測}

\section{2.1 WBGT と発汗密度、脱水密度、飲水密度の関係}

Fig. 6 に、WBGT と SR, RBWL, RWI それぞれの関係を示す。

(a)SR は、VWW 有無に関係なくWBGT と有意な相関関係 $(\mathrm{p}<0.05)$ があり、特に VWW を着用しないと WBGT $=22 \sim 30^{\circ} \mathrm{C}$ で SR が 10〜 $15 \mathrm{~g} /(\mathrm{kg} ・ \mathrm{~h})$ に急激に増大寸る。(b)RBWL は、VWW な しのみ WBGT と有意な相関関係 $(\mathrm{p}<0.01)$ があり、WBGT $=22 \sim 30^{\circ} \mathrm{C}$ で RBWL は $5 \sim 12 \mathrm{~g} /(\mathrm{kg} \cdot \mathrm{h})$ に急激に増大寸る。VWW を着用して いるとWBGTに関係なく $5 \sim 6.5 \mathrm{~g} /(\mathrm{kg} \cdot \mathrm{h})$ で概ね一定である。(c)RWI は、VWW の有無に関わらず WBGT と有意な関係が見られない。

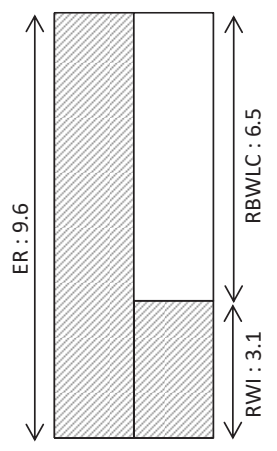

(a) With VWW

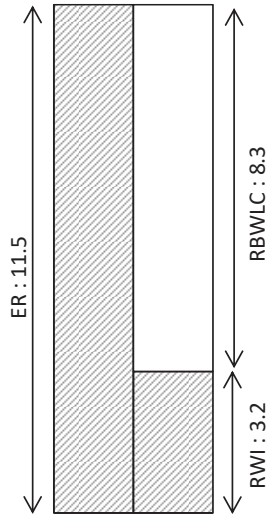

(b) Without VWW
Fig. 8 Comparisons of ER, RWI and RBWLC between with and without VWW measured in a construction site. Unit: $\mathrm{g} /(\mathrm{kg} \cdot \mathrm{h})$

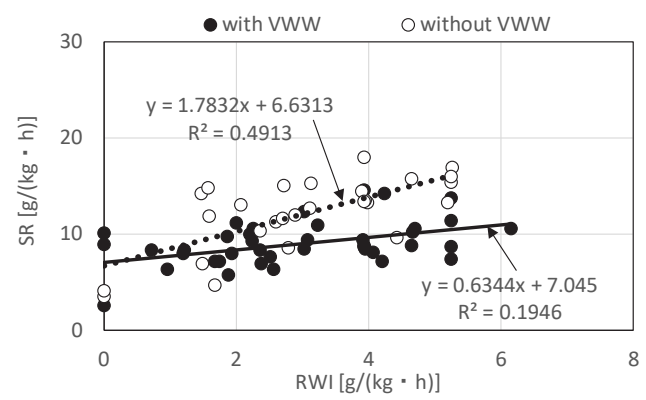

(a) Sweat rate

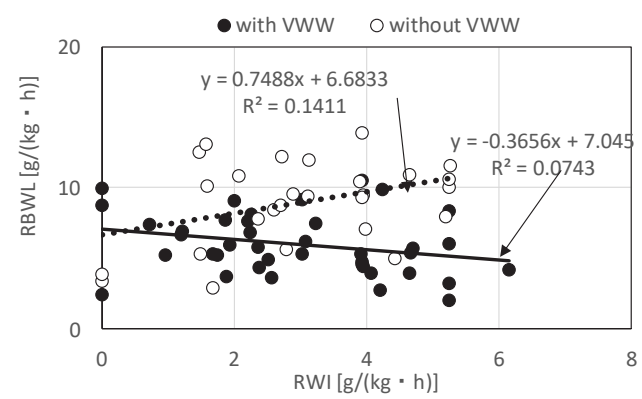

(b) Rate of naked body weight loss

Fig. 9 Relation between rate of water intake, and sweat rate and rate of body weight loss with and without VWW measured in a construction site.

これらの結果から、VWW 非着用やWBGT 上昇により SR が多くな るにも関わらず、VWW やWBGT は RWI には影響しないため、 VWW 非着用の場合に RBWL は高くなり、かっWBGTに伴って上 昇すると考えられた。

比較のために、バレーボール部員 7)、野球部員 ${ }^{8)}$ の結果を Fig.6 に 示す。代謝量はそれぞれ $180,150 \mathrm{~W} / \mathrm{m}^{2}$ と想定され 12 、現場の平均 $107 \mathrm{~W} / \mathrm{m}^{2}$ より高かった。(a)SR は、バレーボールは VWW 非着用時 と、野球は VWW 着用時とほぼ同等であった。一方、(c)運動部員の RWI は、建設作業員よりも 2 倍以上多いのが特徴であった。この結 果、(b)の RBWL において、バレーボール部員が VWW 着用時とほ ぼ同程度、野球部員は VWW 着用時よりも半分以下であった。運動 現場では、SR が WBGT に伴って上昇するが、RWI も WBGT に伴 


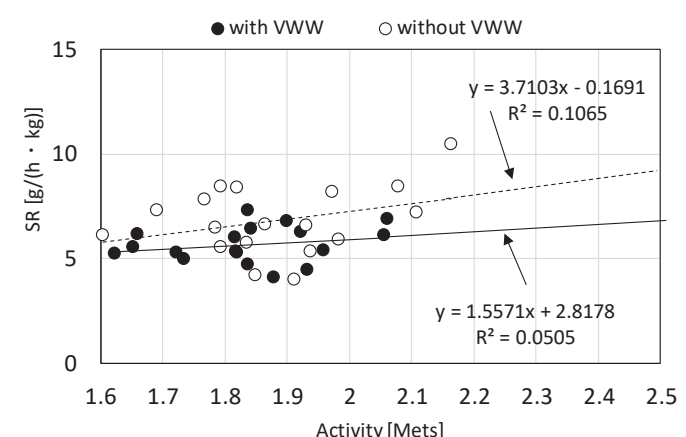

(a) Sweat rate



(b) Rate of water intake

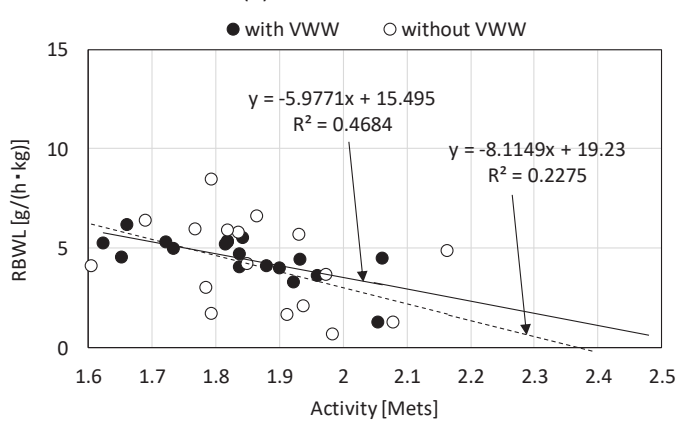

(c) Rate of naked body weight loss

Fig. 10 Relations between activity and sweat rate, rate of water intake, and body weight loss with and without VWW measured in artificial climate chamber at a fixed temperature $\left(34^{\circ} \mathrm{C}\right)$.

い有意に増大寸るので、RBWL は WBGT と関係なくほぼ一定に保 たれる。しかし建設現場では、運動現場と同様に WBGT の上昇に 伴い、SR が高くなる傾向が見られるものの、RWI が WBGT の上 昇に伴い増大せず、しかも運動部員より顕著に低いので、運動現場 のようにRBWLをWBGT に対して一定に維持することができない。 そのような状況でも VWW を着用することで SR を低減できるため、 RBWL を低減できることが示された。

\section{2.2 水分量・活動量における VWW の効果}

Fig. 7 に、RWI, RBWLC, ER, 活動量の $\mathrm{t}$ 検定の結果を示す。 (a)RWI では、VWW あり (平均值 $3.1 \mathrm{~g} /(\mathrm{kg} \cdot \mathrm{h})$ ), VWW なし(平均 值 $3.2 \mathrm{~g} /(\mathrm{kg} \cdot \mathrm{h})$ ) で有意な差が認められなかった。AC 実験に比べて 若干高くなったが概ね $3 \mathrm{~g} /(\mathrm{kg} \cdot \mathrm{h})$ に留まった。(b)RBWLC では、 VWW を着用しない(平均值 $8.3 \mathrm{~g} /(\mathrm{kg} \cdot \mathrm{h})$ ) と、VWW 着用時(平均值 $6.5 \mathrm{~g} /(\mathrm{kg} \cdot \mathrm{h}))$ より有意に高值を示した $(\mathrm{p}<0.05)$ 。 (c)ER も同様に、
VWW を着用しない(平均値 $11.6 \mathrm{~g} /(\mathrm{kg} \cdot \mathrm{h})$ ) と、 VWW 着用時(平均値 $9.6 \mathrm{~g} /(\mathrm{kg} \cdot \mathrm{h}))$ より有意に高值を示した $(\mathrm{p}<0.05) 。 \mathrm{VWW}$ を着用しな い方が蒸発密度は高いにも関わらず、飲水密度が VWW 着用時と同 等であるため、着衣時脱水密度は有意に高かったと考えられた。(e) 活動量は、VWW あり (平均值 2.4Mets) と VWW なし(平均值 2.38Mets)には有意な差が認められなかったが、 $\mathrm{AC}$ 実験の平均值 1.8Mets より $30 \%$ 高くなった。現場の被験者は、 5,6 階の作業場ま での階段の昇り降りと、材料の運搬に起因する歩行作業があるため、 歩行が制限される人工気候室内での模擬作業に比べて、活動量が大 きかったと考えられた。建設現場の $\mathrm{ER}$ が、 $\mathrm{AC}$ 実験の平均值 $4.2 \mathrm{~g} /(\mathrm{kg} \cdot \mathrm{h})$ の $2 \sim 3$ 倍の概敞 $10 \mathrm{~g} /(\mathrm{kg} \cdot \mathrm{h})$ になったのは、活動量の 差に起因寸ると考えられる。

Fig. 8 に、VWW 有無における RWI, RBWLC, ER の関係を示す。 $\mathrm{AC}$ 実験では RBWLC が VWW 着用時(平均值 $3.1 \mathrm{~g} /(\mathrm{kg} \cdot \mathrm{h})$ )、VWW 非着用時(平均值 $1.9 \mathrm{~g} /(\mathrm{kg} \cdot \mathrm{h})$ ) であったのに対し、現場では概ね VWW 着用時 2 倍、VWW 非着用時で 4 倍になっている。その結果、 ER に対する RWI の割合はVWW 着用、非着用で、それぞれ $32 \%$ 、 $28 \%$ となっており、SCC を考慮するとさらに水分補給率(SR に対す るWI の割合) は低くなる。これらは、ほぼ同様の WBGT 環境での 野球、サッカーの水分補給率、それぞれ $92.4 \% 、 58.4 \% 13)$ をきく 下回る。

\section{2.3 飲水密度と発汗密度、脱水密度の関係}

Fig.9 に、現場での RWI と SR, RBWL の関係を示す。

$\mathrm{AC}$ 実験では、VWW を着用しないと、RWI に関わらず SR はほ ぼ一定の範囲にあった(Fig.5(a))。それに対し現場では、SR が有意 な相関関係 $(\mathrm{p}<0.01)$ で上昇し、 $\mathrm{RWI}=4 \mathrm{~g} /(\mathrm{kg} \cdot \mathrm{h})$ では $\mathrm{SR}=13 \mathrm{~g} /(\mathrm{kg} ・$ h) となり、AC 実験より約 $6 \mathrm{~g} /(\mathrm{kg} \cdot \mathrm{h})$ 高くなった。これには、無効 発汗が寄与していると考えられた。その結果、RBWL は Fig.5(b)の ように RWI の増加に伴って減少せず、 $R W I=4 \mathrm{~g} /(\mathrm{kg} \cdot \mathrm{h})$ で $\mathrm{RBWL}=10 \mathrm{~g} /(\mathrm{kg} \cdot \mathrm{h})$ となった。

VWW を着用すると、SR は RWI との間に有意な相関関係 $(\mathrm{p}<$ 0.01)があるが、AC 実験と同様に RWI の増加に対して概ね一定な ので、RWI が高くなるに従いVWW なしの SR との差が大きくなっ た。その結果、RBWL も Fig.5(b) と同様に、RWI の増加に伴い減少 し、RWI $=4 \mathrm{~g} /(\mathrm{kg} \cdot \mathrm{h})$ で $\mathrm{RBWL}=6 \mathrm{~g} /(\mathrm{kg} \cdot \mathrm{h})$ となり、VWW 着用時と 比較すると $4 \mathrm{~g} /(\mathrm{kg} \cdot \mathrm{h})$ 低くなった。

森本は、すでに脱水状態にある場合には水分補給時に発汗量が増 加するが、充分水分を補給されている場合には発汗量は増加しない としている ${ }^{14)}$ 。VWW を着用しない場合、脱水密度は飲水密度が上 昇するにつれて高くなり、AC 実験との差が大きくなることから、 既に脱水状態であると考えることができる。それに対し、VWWを 着用すると、発汗密度が飲水密度に対して $\mathrm{AC}$ 実験とほぼ同じ傾き となり、VWW なしに比べて発汗密度が抑えられた結果、脱水密度 を飲水密度の増加に伴い低減させることができることから、充分水 分が補給されている状況と想定された。

\section{4. 考察}

\section{1 人工気候室実験での活動量と飲水密度 · 発汗密度 $\cdot$ 脱水密度の 関係}

Fig.10に、活動量と RWI, SR, RBWL の関係を示す。（a) SR は、 
活動量との間に有意な相関関係が認められなかったが、活動量が高 くなるに従い、SR が若干大きくなる傾向が見られた。（b)RWI で は、VWW 有無ともに、活動量と有意な相関関係 $(\mathrm{p}<0.01)$ があり、 活動量の増加に伴って RWI が大きくなり、VWWを着用しない方が VWW 着用時に比べて傾きが大きかった。(c)RBWLは、VWW を着 用すると活動量と有意な相関関係 $(\mathrm{p}<0.01)$ があり、活動量が高くな るに従い、RBWL は小さくなる。VWW なしはデータのバラツキが 大きく、活動量と有意な相関関係が認められなかったが、VWW 着 用時と同様に活動量が高くなるに従い、RBWL が小さくなる傾向が 見られた。RWI はVWW 着用有無で差はあるが、活動量に依存して 大きくなる一方、本実験範囲では SR は活動量に関わらずほぼ一定 であるため、RBWL はVWW に関係なく活動量が高くなるに従い減 少する。これは、活動量が高くても、RWI を大きくすることによっ て、RBWL が上がらずかえって小さくできることを示唆している。 3.1.2では、VWW あり・なしに関係なく、RBWL は RWI の増大に よって減らすことができるとしているが、この RWI の増大は、活 動量が高くなったことに起因すると想定できる。また、Fig.10(a)で、 回帰直線を外挿すると活動量が高くなるにつれ、VWW を着用しな い方が発汗量は高くなる。これは、ER が、低活動量の $\mathrm{AC}$ 実験で は VWW の有無で有意差がなかったのに対し、活動量が大きい CS 実測では、VWW を着用しない方が有意に高くなった(Fig.7(c))結果 と符合している。

\section{2 脱水量、脱水率の一日の経時変動における VWW 有無の影響}

休秘時間・昼休みを含めた脱水状況を把握するために、建設現場 の着衣時体重減少量 (BWLC [g]) と脱水率の一日の経時変化を評 価した。本来は、文献 7),8)のスポーツ選手のように半裸体状態 (パ ンツのみ）での体重を測定して RBWL を求める必要があるが、現 場の作業員を対象に行うことは困難である。現場では活動量が大き いため、RBWLC (VWW あり、VWW なしでそれぞれ平均值が 6.5, $8 \mathrm{~g} /(\mathrm{kg} \cdot \mathrm{h})(\mathrm{Fig} .8))$ は SCC より充分に大きいと考え、本報では BWLC [g] を用いて評価する。暑い日、涼しい日における被験者 5 名の平均 BWLC と平均脱水率の日変動を VWW の有無で比較した 結果を示寸 (Fig.11, 12)。BWLC は、各測定時の着衣体重から実測 開始時 (AM1 作業開始時) 着衣体重を差し引くので、RBWLC と異 なり、マイナスの值になる。被験者 5 名の平均体重は $66.7 \mathrm{~kg}$ であ る。脱水率（Dewatering Ratio）は、AM1 作業開始時を基準とし て、以下の式(7)から求める。

脱水率 $(\%)=(\mathrm{AM} 1$ 作業開始時体重一各作業時間帯後体重 $)$

/ AM1 作業開始時体重 $\times 100$

まず、BWLC の VWW 有無での差について $\mathrm{t}$ 検定した。暑い日で は、VWW なし群(平均值 981.6g)は、VWW あり群(平均值 $732.2 \mathrm{~g}$ ) に対し有意に高值を示した $(\mathrm{p}<0.05)$ 。WI（飲水量, $[\mathrm{g}])$ は、VWW な し群(平均值 165.9g) と VWW あり群(平均值 $171.3 \mathrm{~g}$ ) で有意な差がな く、活動量も VWW なし群(平均值 2.49Mets) と VWW あり群(平均 值 2.29Mets)で有意な差がなかった。VWW が BWLC を低減する要 因として、活動量が高くなるとVWW を着用した方が発汗量は低減 すること(Fig. 10(a))や、WBGT の高い環境で発汗量が低減すること (Fig. 6(a))が考えられた。涼しい日では、作業時間帯の脱水量の VWW あり群(平均值 $692.0 \mathrm{~g}$ ) と VWW なし群(平均值 752.3g) での有 意な差は認められなかった。

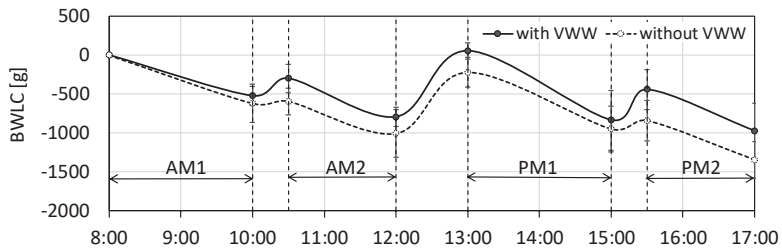

(a) Fluctuation of BWLC

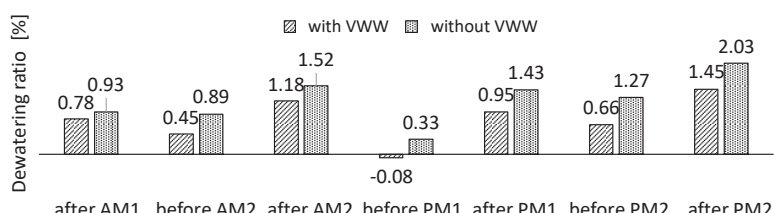

after AM1 before AM2 after AM2 before PM1 after PM1 before PM2 after PM2

(b) Dewatering ratio

Fig. 11 BWLC and dewatering ratio (hot days).

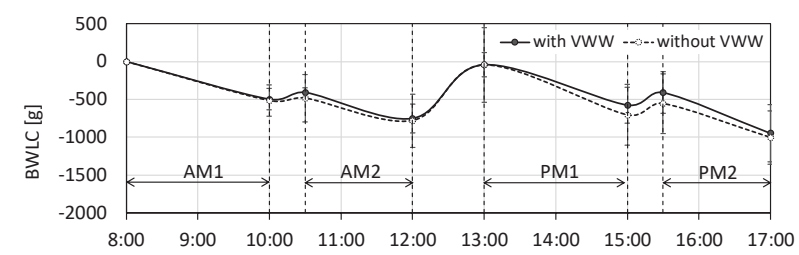

(a) Fluctuation of BWLC

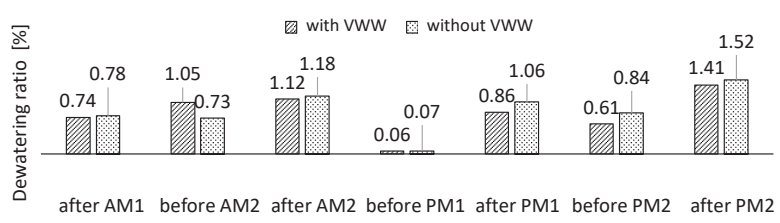

(b) Dewatering ratio

Fig. 12 BWLC and dewatering ratio (moderate days).

次に、昼休みと午前、午後それぞれの休惒時間後の体重から休輴 時間前の体重を差し引いて休鄎時間中の水分補給量とし、VWW あ り・なしについて $\mathrm{t}$ 検定した。暑い日では、VWW なし群(平均值 295.0g)はVWW あり群(平均值 421.3g)に対し有意に水分補給量が 少ない $(\mathrm{p}<0.05)$ 。涼しい日では、VWW あり群(平均值 $322.7 \mathrm{~g}$ ) と VWW なし群(平均值 $313.2 \mathrm{~g}$ )での有意な差は認められなかった。 VWW 有無で休毠時間中の飲水量・尿量が概水変わらないと想定す ると、VWW なしではVWW ありに比べて、休㕷時間中に着衣残留 汗の蒸発によって失われる水分量が多いことと、昼休みや休款時間

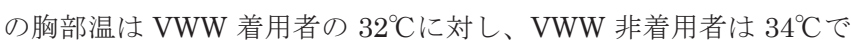
概衫 $2^{\circ} \mathrm{C}$ 高かったため 11 、休款時間中の発汗量が多かったことが要 因として考えられる。

さらに、暑い日の VWW なしでの AM2, PM2 の作業終了時の平均 脱水率は、それぞれ $1.52,2.03$ になり、WBGT $=26 \sim 28^{\circ} \mathrm{C}$ の環境で

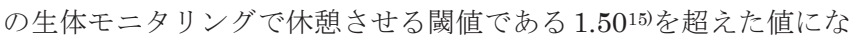
る。それに対して、VWW ありでの AM2, PM2 の作業終了時の平均 脱水率は、それぞれ $1.18 ， 1.45$ で 1.50 を下回った。この VWW 有 無の平均脱水率の差には、作業時間中の脱水量の差に加えて、昼休 みを含めた休貌時間中の水分補給量の差も寄与していると考えられ る。一方、涼しい日での AM2, PM2 の作業終了時の平均脱水率は、 
VWW 有無とも 1.5 以下であった。

島村らは、運動部の運動(2４ 時間)で 0.7〜 $1.8 \mathrm{~kg}$ 発汗した後、 1 時間に飲めるだけ飲んでも $0.4 \sim 1.0 \mathrm{~kg}$ 程度の水負債が続いた ${ }^{16)}$ と 指摘している。建設現場では、熱中症の最も発生件数が多い時間帯 は、通常最高気温を記録した後に、気温が低下寸る時間帯の $15 \sim 17$ 時であるとの指摘がある 17)。これらの結果から、厳しい暑熱環境の 建設現場では、作業時間中の脱水に加えて、昼休みを含めた休䈍時 間の水分補給の不足による水負債が、午後作業終了時の脱水率増加 の要因となり、15〜17 時に熱中症による労働災害が多い 15) 17)原因 である可能性がある。

文献 18 )では、日平均 $\mathrm{WBGT}=27.6 \sim 28^{\circ} \mathrm{C}$ の環境で、 23 人(型枠大 工 7 人、解体工 3 人、清掃工 2 名、鉄骨工 2 名、断熱工 2 名、大工 2 名、他 5 名)の屋内外作業を対象とした 3 日間の実測では、午前の 初期体重に対する体重減少率は、昼食時にほぼ回復し、午後再度増 加し、作業終了時の平均は $1.3 \% て ゙ 、 5$ 人の作業員が $2 \%$ を超えてい た。本現場の実測では、文献 18) と同等の環境の暑い日において、 同じ条件の VWW なしの作業員の作業終了時の平均脱水率は $2.03 \%$ であり、 2 人の作業員が $2 \%$ 超えていた。文献 18 )の建設作業員の 飲水密度は $0.2 \sim 0.4 \mathrm{~L} / \mathrm{h} / 70 \mathrm{~kg}$ で、これは概ね $3 \sim 6 \mathrm{~g} /(\mathrm{kg} \cdot \mathrm{h})$ に相当 し、本現場の飲水密度の範囲 $0 \sim 6 \mathrm{~g} /(\mathrm{kg} \cdot \mathrm{h})$ と概水一致しており、 現場の作業員の自由な飲水密度は、 $6 \mathrm{~g} /(\mathrm{kg} \cdot \mathrm{h})$ 程度が限界であると 推定された。

\section{5. まとめ}

建設現場での飲水と VWW が脱水の低減に及ぼす効果について、 環境(WBGT) ・活動量の影響を考慮に入れて、先行研究の運動現場 と比較しながら、人工気候室実験 $\left(34^{\circ} \mathrm{C}, 50 \%\right)$ と現場実測の結果を 用いて評価した。

人工気候室実験では、運動現場と同様に、VWW 有無に関わらず 発汗密度は飲水密度に依存せずほぼ一定なので、飲水密度が増える ことで脱水量は低下した。この飲水密度の増大は、活動量が高くな ったことに起因すると考えることができ、活動量が高くなっても、 飲水密度を大きくすることによって、脱水密度を小さくできること が示唆された。

実際の建設現場では、VWW を着用しないと WBGT の上昇に伴い 発汗密度が高くなったが、運動現場のように WBGT の上昇に伴い 飲水密度を増大させることができなかったため、脱水密度も増大し、 運動現場の 2 倍 $(10 \mathrm{~g} /(\mathrm{kg} \cdot \mathrm{h}))$ 以上にも達した。また、飲水密度の 上昇に伴い、発汗密度が実験のように概ね一定とならず高くなった。 すでに脱水状態にある場合には水分補給時に発汗密度が増加するが、 ヒトが発汗により脱水が生じた後に飲水しても直ちに脱水を回復で きない、自発的脱水に起因しているとも考えられた 19)。その結果、 飲水密度の上昇に伴い脱水密度が高くなり、同じ飲水密度に対して 実験の 2 倍になった。一方、VWW を着用すると、WBGT の上昇に 伴う発汗密度の上昇を低く抑えることができた。WBGTの上昇に伴 い飲水密度は増加しなかったものの、脱水密度を VWW 非着用時の 概小 $1 / 2$ に低減できた。他方、蒸発密度に対する飲水密度は $30 \%$ 程 度で、着衣残留汗密度を考慮すると水分補給率はさらに低下寸ると 考えられ、同 WBGT 環境での野球、サッカーの水分補給率である 92.4\%、58.4\% ${ }^{13)}$ を大きく下回った。
休憩時間・昼休みを含めた脱水状況を評価するために、作業時間 前後に測定した脱水量・脱水率の一日の経時変化を評価した。暑い 日 $\left(\mathrm{WBGT}=27 \sim 31^{\circ} \mathrm{C}\right)$ 、涼しい日 $\left(\mathrm{WBGT}=22 \sim 26^{\circ} \mathrm{C}\right)$ それぞれの 2 日間において、被験者 5 名について VWW 有無で比較した。暑い日 にVWW を着用しないと、午前、午後の作業終了時の平均脱水率は、 それぞれ 1.52, 2.03 となり、生体モニタリングで休稤させる閾值で ある 1.50 を超えた值になった。それに対し、暑い日でも VWWを 着用すると午前・午後作業終了時の脱水率は 1.5 以下だった。以上 のように、建設現場での VWW は脱水の低減に有効であり、暑熱環 境が厳しい現場での熱中症対策として、VWW 着用の義務化が望ま れる。

建設現場での水分補給が運動現場よりも少ないことの対策として、 環境温度が高い場合には休䕀頻度の増加により、飲水頻度を多くす るように、管理者の指導計画の改善が挙げられる 20$)$ 。一方運動現場 では、給水回数を増加させる強制飲水では、 1 回の飲水量は自由飲 水より低值であり、必要量に見合った飲水量の調節が行われていて、 自由飲水で水分補給の目的は達成できるとしているが、供給時の容 器の形態と練習中に容器が選手の近くにあることも補給率を高める 条件となるとしている 13)。現場で水分補給率を向上させるために、 給水回数を増加させる強制飲水を試みることや、容器の形態と作業 中の容器の作業員との位置関係の工夫も、今後必要である。一方、 人工気候室の模擬作業では、飲水密度の変化に関わらず発汗密度が 概水一定だったので、飲水密度が増大寸るに従い脱水密度が低減し たが、活動量が大きい現場では、脱水状態や自発的脱水の影響で、 飲水密度が大きくなるに従い発汗密度が高くなるために、脱水密度 も高くなる。脱水状態や自発的脱水の影響の対策としては、午前・ 午後の作業前の時間帯からの飲水が挙げられる。

\section{謝辞}

実験と現場実測にご協力いただいた東京・札幌の被験者の皆様、 データ解析にご尽力いただいた北海道大学工学院空間性能システム 専攻修士 1 年の山田稜君に深謝します。貴重な文献を無償で提供し ていただいた日本スポーツ協会殿に感謝します。

注

注 1) 文献 3)では、被験者の飲水量が 0 だったので、回帰式は ER と SR の関 係と見なした。本実験では飲水があったので、回帰式を ER と SR の関 倸として用い、RBWL は RWI を差し引いて求めた。

\section{参考文献}

1) Yamazaki, K., Suga, S., Takahashi, N., Kuwabara, K., and Kobayashi, K.: The Psychological and Physiological Effects of Air-conditioned Wear and Other Functions on Construction Workers, No.1 Actual Investigation at Active Construction Site, Journal of Environmental Engineering (Transactions of AIJ), Vol. 83, No. 747, pp. 453-463, 2018. 5 (in Japanese)

山㠃慶太，菅重夫，高橋直，荣原浩平，小林宏一郎：ファン付き作業服が 建設作業員の生理・心理反応に及ぼす影響と他の要因に関する研究, 建 設現場における実態調査その 1 , 日本建築学会環境系論文集, 第 83 巻, 第 747 号, pp. 453-463, 2018. 5

2) Yamazaki, K., Suga, S., Kuwabara, K., Hamada, Y., Syu, S., Nakano, R., Kobayashi, K., and Takahashi, N.: Effect of Simulated Work in Artificial Climate Chamber on Physiological and Psychological 
Responses of Construction Workers with Air-Conditioned Wear, Journal of Environmental Engineering (Transactions of AIJ), Vol. 83, No. 748, pp. 543-553, 2018. 6 (in Japanese)

山崎慶太, 菅重夫, 葉原浩平, 濱田靖弘, 朱楚奇, 中野良亮, 小林宏一郎, 高橋直：人工気候室での模擬作業がファン付き作業服を着用した建設作 業員の生理・心理反応に及ぼす影響, 日本建築学会環境系論文集, 第 83 巻, 第 748 号, pp.543-553, 2018.6

3) Kuwabara, K., Yamazaki, K., Suga, S., Kobayashi, K., Hamada, Y., and Takahashi, N.: Effect of Ventilated Work Wear and Working Schedule on Physiological and Psychological Responses of Construction Workers, No.2 Actual Investigation at Active Construction Site, Journal of Environmental Engineering (Transactions of AIJ), Vol. 84, No. 756, pp. 151-159, 2019. 2 (in Japanese).

荣原浩平, 山㠃慶太, 菅重夫, 小林宏一郎, 濱田靖弘, 高橋直：ファン付 き作業服と作業時間帯が建設作業員の生理 - 心理反応に及ぼす影響, 建 設現場における実態調査その 2 , 日本建築学会環境系論文集, 第 84 巻, 第 756 号, pp.151-159, 2019.2

4) Kondo, K.: Thermoregulatory responses in humans, Kobe University Repository, Vol. 5, No. 2, pp. 55-66, 1998. 3 (in Japanese)

近藤徳彦: 人の体温調節反応, 神戸大学発達科学部研究紀要, $5,2, \mathrm{pp}$. 55-66, 19983

5) Yoshida, T.: Introduction of studies on the prevention of heat disorders in Japan, Jpn. J. Biometeor., Vol. 52, No. 2, pp. 97-104, 2015 (in Japanese)

芳田哲也：日本における熱中症予防研究, 日生気誌, Vol. 52, No. 2, pp. 97-104, 2015

6) Sato, Y., and Niwa, K.: Effects if drinking on sweating and body cooling during exercise, Jpn. J. Phys. Fitness Sports Med., Vol. 46, pp. 113-122, 1997 (in Japanese)

佐藤靖丈, 丹羽健市: 運動時の飲水が発汗反応及び体温冷却に及ぼす影 響, 体力科学, Vol. 46, pp. 113-122, 1997

7) Niwa, K., Nakai, S., Asayama, M., Hirata, K., Hanawa, K., Igawa, S., Hirashita, M., Sugawara, M., and Itou, S.: A survey of ambient temperature, drinking, sweating, and body temperature, Jpn. J. Phys. Fitness Sports Med., Vol. 45, pp. 151-158, 1996 (in Japanese) 丹羽健市, 中井誠一, 朝山正巳, 平田耕造, 花輪啓一, 井川正治, 平下 政美, 菅原正志, 伊藤静夫 : 運動時の環境温度と飲水量・発汗量及び体 温に関する実態調査, 体力科学, Vol. 45, pp. 151-158, 1996

8) Nakai, S., Yoshida, T., Yorimoto, A., Okamoto, N., and Morimoto, T.: Relationships between environmental temperature (WBGT) and body weight loss, fluid intake and sweat loss during physical exercise, Jpn. J. Phys. Fitness Sports Med., Vol. 43, pp. 283-289, 1994 (in Japanese) 中井誠一, 芳田哲也, 寄本明, 岡本直輝, 森本武利: 運動時の発汗量と 水分摂取量に及ぼす環境温度(WBGT)の影響, 体力科学, Vol. 43, pp. 283-289, 1994

9) Yamada, Y., Kaneuchi, Y., Yamazaki, K., Suga, S., Kuwabara, K., Kubo, G., Hamada, Y., Kobayashi, K., and Dempoya, A. :Study on the effect of Ventilated Working Wear on physiological and psychological responses of construction workers-Part VIII, $42^{\text {nd }}$ Symposium on Human-Environment. System, pp. 19-22, 2018. 12 (in Japanese) 山田稜, 金内遥一郎, 山崎慶太, 菅重夫, 葉原浩平, 久保元人, 濱田靖弘, 小林宏一郎, 傅法谷郁乃：ファン付き作業服が建設作業員の生理 - 心理 反応に及ぼす影響に関する研究, 第 8 報人工気候室内における水分損失 と皮膚温の関係, 第 42 回人間-生活環境系シンポジウム報告集, pp.19-22, 2018.12

10) Observed data on weather data in July 2018 at Sapporo, Website of Ministry of Land, Infrastructure and Japan Meteorological Agency, (accessed 2019. 11. 25)

国土交通省気象庁ホームページ，過去の気象データ検索 : 札幌 2018 年 6 月（日ごとの值）主な 要素 https://www.data.jma.go.jp/obd/stats/etrn/view/daily_s1.php?prec_no=14\&bloc k_no $=47412$ \&year $=2018 \&$ month $=6 \&$ day $=\&$ view $=$

(参照 2019.11.25)

11) Yamazaki, K., Suga, S., Kuwabara, K., Hamada, Y., Kaneuchi, Y., and Kobayashi, K.: Study on the effect of Ventilated Working Wear on physiological and psychological responses of construction workers-PartVII, $42^{\text {nd }}$ Symposium on Human-Environment. System, pp. 15-18, 2018. 12 (in Japanese)

山崎慶太, 菅重夫, 莱原浩平, 濱田靖弘, 金内遥一郎, 小林宏一郎：ファ ン付き作業服が建設作業員の生理・心理反応に及ぼす影響に関する研究, 第 7 報建設現場における水分損失と皮膚温の関係, 第 42 回人間-生活環 境系シンポジウム報告集, pp. 15-18, 2018. 12

12) Ministry of Health, Labor and Welfare, Kenkou-zukuri no tameno undou-shishin, 2006 厚生労働省 : 健康づくりのための運動指針 2006

13) Nakai, S. Yoshida, T. Yorimoto, and A. Morimoto, T.: Analysis of the Rehydration Process during Physical Training in ot Environment, Desant sports Science, No. 16, pp. 91-106, 1995. 6 (in Japanese)

中井誠一, 芳田哲也, 森本武利: 運動時脱水回復に及ぼす給水方法の影 響, デサントスポーツ科学, No. 16, pp.91-106, 1995.6

14) Morimoto, T.: Undoji no necchusyo-taisaku, Jpn. J. Phys. Fitness Sports Med., Vol. 56, pp. 9-10, 2007 (in Japanese) 森本武利：運動時の熱中症予防, 体力科学, Vol. 56, pp. 9-10, 2007

15) Horie, M.: Nettyusyou o Husegou, Nettyusyou Rodoutaisaku no Kihon, Chyuou Roudou Saigai Boushi Kyokai, 2009 (in Japanese)

堀江正知： 熱中症を防ごう 熱中症予防対策の基本，中央労働災害防止 協会, 2009

16) Shimamura, M., Nakao, F., and Kaneko, K.: Fluid Replacement after Sweating Caused by Physical Exercise and Guidance of Eating and Drinking after Exercise, Jpn. J. Human and Living Environment, Vol. 2, No. 1, pp.75-81, 1995 (in Japanese)

島村実花，中島芙美子，金子佳代子: 運動による発汗後の水分補給の実態 と飲食指導, 人間と生活環境, Vol. 2, No.1, pp. 75-81, 1995

17) Koyama, T., Matsufuji, Y., Koyamada, H., and Yamaguchi, K.: Tendency of Labor Accident on Hot weather Ambience, Journal of Structural Construction Engineering (Transactions of AIJ), No. 600, pp. 17-21, 2006. 2 (in Japanese). 小山智幸, 松藤泰典, 小山田英弘, 山口謙太郎 : 暑中環境における建設災 害の発生傾向に関する研究, 日本建築学会構造系論文集, 第 600 巻, pp. 17-21, 2006. 2

18) Ueno, S., Sakakibara, Y., Hisanaga, N., Oka, T., and Yamaguchi, S.: Heat Strain and Hydration of Japanese Construction Workers during Work in Summer., Annual of work Exposures and Health, Vol. 62, No. 5, pp. 571-582, 2018

19) Morimoto, T.: Suibun-taisya to Nettyusyou, Heisei 3 nendo Nihon taiiku Kyoukai Sports · Ikagaku-Kenkyu-Houkoku, No. VIII Sports-Katsudo ni okeru Nettyusyou-Ziko-Yobou ni Kansuru Kenkyu, Vol. 1, pp. 14-26, 1993 (in Japanese)

森本武利：水分代謝と熱中症, 平成 3 年度日本体育協会スポーツ・医科 学研究報告, No.VIIIスポーツ活動における熱中症事故予防に関する研究— 第 1 報一、pp. 14-26, 1993

20) Kajiwara, Y., Kawashima, S., Itoh. K., Izutsu, S., and Nozaki, T.: Environmental Temperature during Summer Baseball Practice as Viewed from Problems of Heat Stress and Physiological Work Load, Kyouiku-Gakubu Kiyo, Bunkyou Daigaku Kyouiku-Gakubu, No. 36, pp. 73-82, 2002 (in Japanese) 梶原洋子, 川嶋伸次, 伊東浩司, 井筒柴乃, 野崎忠信 : 夏季の野球練習 時の環境温、発汗量、飲水量、脱水率、体温上昇度および心拍反応から みた生体負担度について,「教育学部紀要」文教大学教育学部, No. 36, pp. $73-82,2002$ 
Relation between the sweet rate, body weight loss, water intake, WBGT and activity during construction work

$$
\begin{gathered}
\text { Keita YAMAZAKI }{ }^{* 1} \text {, Kohei KUWABARA }{ }^{* 2} \text {, Shunsuke SOMEYA }{ }^{* 3} \text {, } \\
\text { Yasuhiro HAMADA }{ }^{* 4} \text { and Koichiro KOBAYASHI }{ }^{* 5} \\
{ }^{* 1} \text { Takenaka Research \& Development Institute, Dr.Eng./ } \\
\text { Visiting Prof. of Iwate University } \\
{ }^{* 2} \text { Assoc. Prof., National Institute of Technology, Kushiro College, Dr.Eng. } \\
{ }^{* 3} \text { Assoc. Chief Researcher, Takenaka Research \& Development Institute } \\
{ }^{* 4} \text { Prof., Graduate School of Engineering, Hokkaido Univ., Dr.Eng. } \\
{ }^{* 5} \text { Prof., Dept. of Systems Innovation Engineering, Iwate University, Dr.Eng. }
\end{gathered}
$$

To obtain basic data for prevention of heat stroke during construction work in a hot environment, we analyzed the effects of wearing ventilated work wear (VWW) and water intake (RWI). First, experiments were carried out with nine male form workers in an artificial climate chamber (AC) at $34^{\circ} \mathrm{C}$. Second, measurements were carried out with four male form workers and one male rebar placer at an outside construction site (CS) for four days in August 2017. It was carried out from 8:00 to 17:00 and was divided into four shifts split up by breaks as follows: 8:00 to 10:00, 10:30 to 12:00, 13:00 to 15:00; and 15:30 to 17:00. Activity amount (ACT) was continuously measured. WBGT was measured in the CS. The sweat rate (SR), the rate of naked body weight loss (RBWL, only in the AC), body weight loss while fully clothed (RBWLC), and RWI were each measured and calculated as the difference between the values before and after work per unit time. Evaporation rate (ER) was defined as the sum of RBWLC and RWI. SR in the CS was estimated from the ER by using the regression equation between ER and SR in the AC data.

In the AC experiment, the SR during work was constant and RBWL was negatively correlated with RWI, those were statistically significant, regardless of whether the workers wore VWW. The RWI and SR of workers not wearing VWW were significantly higher than those of workers wearing VWW. RWI increased significantly and RBWL decreased as ACT increased. This is the reason that RBWL was negatively correlated with the RWI in the AC.

In the CS experiments, the SR of workers not wearing VWW increased significantly as WBGT increased, but the RWI did not change significantly; as a result, RBWL increased significantly with WBGT. The SR of individuals wearing VWW, which was lower than that of those not wearing VWW, remained almost constant with increasing WBGT, whereas RWI did not increase with WBGT. As expected from these results, RBWL remained constant as WBGT increased and was consistently lower than that of workers not wearing VWW. The ER of works in the CS was significantly higher than that of those in the AC due to the difference between the averaged ACT in the AC (1.8 Mets) and CS (2.4 Mets). In the CS experiments, we estimated the dewatering ratio (DR) by body weight loss while fully clothed (BWLC), since BWL was not measured. The fluctuation during working shifts of BWLC and DR of workers was compared between those wearing and those not wearing VWW on hot two days. In the shifts, the BWLC of workers not wearing VWW was significantly higher than that of those wearing VWW. Furthermore, in the breaks between shifts, the amount of water recovered by workers not wearing VWW was significantly lower than that of those wearing VWW. As a result, after the last shift, the average DR (2.03) of workers not wearing VWW was higher than that of those wearing VWW (1.53).

We supposed there is a limit to the amount of water that workers in a construction site can drink. Thus, we verified that, in the CS setting, RBWL increased with increasing WBGT mainly due to insufficient RWI, but could be partly decreased by using VWW, which decreased the SR. 